\title{
USAHA PENGAWAS DAN KEPALA SEKOLAH DALAM MENINGKATKAN KINERJA GURU PAI DI MADRASAH KOTA SOLOK
}

\author{
Sarasasti \\ Pengawas Guru Pendidikan Agama Islam Kota Sawahlunto, Sumatera Barat
}

\begin{abstract}
This research concerned on the role of the supervisor and headmaster as an educational consultant for teachers to improve the quality of education. The teachers' job performance can be known from their ability to plan, implement, evaluate and follow up the instructional activities. This research was descriptive qualitative by using interview and documentation as instruments. The results found that there were 7 programs applied to improve the teachers' job performance 1) training teachers' responsibility; 2) training teachers' on instructional implementation; 3) training teachers on instructional evaluation; 4) training teachers' discipline; 5) training teachers' commitment; 6) training teachers' loyalty; and 7) training teachers' motivation. The way the supervisor and headmaster improve the teachers' job performance by giving proportional DP3 score, and they wish to improve the teachers' job performance because there is program of training teachers' responsibility.
\end{abstract}

Keywords: Efforts, Supervisor, Headmaster, Teacher's Job Performance

\section{PENDAHULUAN}

Setiap negara membutuhkan sumber daya manusia yang berkualitas, karena sumber daya manusia yang berkualitas akan memberikan dampak positif terhadap perkembangan pembangunan suatu bangsa dalam berbagai bidang, tidak hanya dalam penguasaan ilmu pengetahuan dan teknologi, akan tetapi juga sikap mental yang baik. Setiap negara selalu berusaha meningkatkan kualitas sumber daya manusia yang dimilikinya dengan meningkatkan kualitas pendidikan bangsanya, karena dengan pendidikan yang berkualitas akan tercipta sumber daya manusia berkualitas, dan juga terhadap peningkatan derajat manusia itu sendiri, sebagaimana yang terdapat dalam firman Allah SWT dalam Q.S Al-mujadalah Ayat 11 "Allah akan meninggikan orang-orang yang beriman di antaramu dan orang-orang yang diberi ilmu pengetahuan beberapa derajat".

Upaya peningkatan kualitas pendidikan dapat dilakukan dengan meningkatkan kinerja para guru, karena para guru yang 
selalu berhadapan langsung dengan peserta didik. Menurut Echols dan Shadily (2005) menjelaskan bahwa kata kinerja berasal dari bahasa Inggris yang merupakan terjemahan dari "performance" yang berarti pekerjaan, perbuatan, pertunjukan. Kemudian menurut Depdikbud istilah kinerja dapat diartikan sebagai 1) sesuatu yang dicapai, 2) prestasi yang diperli-hatkan, 3) kemampuan.

Pengawas merupakan tenaga kependidikan yang peranannya sangat penting dalam meningkatkan kinerja guru di sekolah. Pengawas sekolah berfungsi sebagai supervisor baik supervisor akademik maupun supervisor manajerial. Sebagai supervisor akademik, pengawas sekolah berkewajiban membantu kemampuan profesional guru agar guru dapat meningkatkan mutu proses pembelajaran. Sedangkan sebagai supervisor manajerial, pengawas berkewajiban membantu kepala sekolah agar mencapai sekolah yang efektif.

Praktik kepemimpinan kepala sekolah yang dijiwai dengan kriteria-kriteria sebagaimana disebutkan di atas, akan dapat membentuk persepsi guru yang positif terhadap kepemimpinan kepala sekolah. Bila persepsi guru positif terhadap kepemimpinan kepala sekolah, mereka akan cenderung mengikuti aturan-aturan yang berlaku di sekolah dengan penuh kesadaran, oleh karena itu, kepala sekolah harus mampu melaksanakan tugas dan fungsinya dengan baik.

Kinerja guru merupakan suatu wujud aplikasi dari segala potensi yang dimiliki oleh seorang guru. Kinerja guru dapat diketahui dari kemampuannya dalam merencanakan, melaksanakan, mengevaluasi dan melakukan tindak lanjut dalam kegiatan belajar mengajar. Kinerja guru menunjukkan kemampuan dalam mengintegrasikan tujuan, materi, metode, sarana dan prasarana, sumber belajar, dan unsur-unsur lainnya yang dapat mendukung dalam pelaksanaan proses belajar mengajar di kelas.

Kinerja guru dapat dilihat dari kemampuan dalam melaksanakan tugas. Tugas utama seorang guru adalah mengajar, mendidik dan melatih. Sejalan dengan tugas guru, menurut Yasin (2000) ada tiga aspek performance guru di antaranya 1) kemampuan profesional, mencakup penguasaan pelajaran dari bahan yang diajarkan, penguasaan dan penghayatan atas landasan dan wawasan kependidikan dan keguruan, penguasaan proses-proses kependidikan, keguruan dan pembelajaran siswa; 2) kemampuan sosial, mencakup kemampuan untuk menyesuaikan diri kepada tuntutan kerja dan lingkungan sekitar pada waktu membawakan tugasnya sebagai guru; 3) kemampuan personal guru, mencakup penampilan sikap yang positif 
terhadap keseluruhan tugasnya sebagai guru terhadap keseluruhan situasi pendidikan beserta unsur-unsurnya; pemahaman, penghayatan, nilai-nilai yang seyogyanya dianut oleh guru; penampilan upaya untuk menjadikan dirinya sebagaimana panutan dan teladan bagi para siswanya.

Peningkatan kinerja guru ada beberapa faktor yang mempengaruhinya sebagaimana yang dikemukakan oleh Mahmudi (2005) sebagai berikut 1) faktor pengawas meliputi pengawasan akademik (teknis pendidikan atau pembelajaran), pengawasan manajerial (administrasi dan manajemen sekolah);

2) faktor kepemimpinan kepala sekolah meliputi kualitas dalam memberikan dorongan, semangat, arahan, dan dukungan yang diberikan manajer; 3) faktor tim meliputi kualitas dukungan, semangat yang diberikan oleh rekan satu tim, kepercayaan sesama tim, kekompakan anggota tim; 4) faktor sistem meliputi sistem kerja, fasilitas kerja yang diberikan oleh organisasi, proses organisasi, dan kultur kinerja dalam organisasi.

Beberapa keterangan di atas, dapat diketahui bahwa peningkatan kinerja guru tidak hanya dipengaruhi oleh satu komponen saja, namun banyak komponen yang ikut terlibat di dalamnya, salah satu di antaranya adalah pengawas. Peranan pengawas adalah menjaga dan membimbing guru agar tetap profesional dengan kinerja yang memuaskan dan sesuai dengan target yang ditentukan.

\section{PENGAWAS PENDIDIKAN AGAMA ISLAM}

Arikunto (2001) menyatakan secara etimologi kata supervisi berasal dari istilah Inggris "supervision", terdiri dari dua kata "super (lebih)" dan "vision (melihat)", yang berarti melihat dari atas, dan melihat dengan teliti pekerjaan secara keseluruhan. Sedangkan orang yang melakukan supervisi tersebut, dikenal dengan supervisor atau pengawas. Menurut Thaib \& Subagio (2007) bahwa pengawasan pendidikan atau supervisi pendidikan adalah pembinaan kearah perbaikan situasi pendidikan pada umumnya dan peningkatan mutu belajar mengajar di kelas pada khususnya.

Tugas pokok pengawas pendidikan adalah melakukan penilaian dan pembinaan dengan melaksanakan fungsi-fungsi supervisi, baik supervisi akademik maupun supervisi manajerial. Untuk lebih jelasnya tugas pokok pengawas yang dituliskan oleh Sahertian (2000) sebagai berikut a) Inspecting/Pengawasan; b) Advising/ Menasehati; c) Monitoring/Memantau; d) Coordinating/mengkoordinir; dan e) Reporting. 
Mengacu pada SK Menpan nomor 118 tahun 1996, Keputusan bersama Mendikbud Nomor 03420/O/1996 dan Kepala Badan Administrasi Kepegawaian Negara nomor 38 tahun 1996 serta Keputusan Mendikbud nomor 020/U/1998 dapat dikemukakan tentang tugas pokok dan tanggung jawab pengawas sekolah yang meliputi a) melaksanakan pengawasan penyelenggaraan pendidikan di sekolah sesuai dengan penugasannya pada TK, SD, SLB, SLTP dan SLTA; dan b) meningkatkan kualitas proses pembelajaran dan hasil prestasi belajar/bimbingan siswa dalam rangka mencapai tujuan pendidikan. Tugas pokok yang pertama merujuk pada supervisi atau pengawasan manajerial sedangkan tugas pokok yang kedua merujuk pada supervisi atau pengawasan akademik. Pengawasan manajerial pada dasarnya memberikan pembinaan, penilaian dan bantuan/ bimbingan mulai dari rencana program, proses, sampai dengan hasil. Bimbingan dan bantuan diberikan kepada kepala sekolah dan seluruh staf sekolah dalam pengelolaan sekolah atau penyelenggaraan pendidikan di sekolah untuk meningkatkan kinerja sekolah. Pengawasan akademik berkaitan dengan membina dan membantu guru dalam meningkatkan kualitas proses pembelajaran/bimbingan dan kualitas hasil belajar siswa.
Peran pengawas sekolah adalah menjaga dan membimbing guru agar tetap profesional. Untuk lebih jelas peranan Pengawasan atau Supervisi meliputi (1) supervisi akademik; dan (2) supervisi manajerial. Kedua supervisi ini harus dilakukan secara teratur dan berkesinambungan oleh pengawas sekolah/ madrasah.

Sebelum melaksanakan supervisi akademik, pengawas sekolah/madrasah menurut Sahertian (2000) hendaknya memiliki peranan khusus di antaranya sebagai a) partner (mitra) guru dalam meningkatkan mutu proses dan hasil pembelajaran dan bimbingan di sekolah/ madrasah binaannya, b) inovator dan pelopor dalam mengembangkan inovasi pembelajaran dan bimbingan di sekolah/ madrasah binaannya, c) konsultan pendidikan dan pembelajaran di sekolah/ madrasah binaannya, d) konselor bagi guru dan seluruh tenaga kependidikan di sekolah/madrasah, dan, e) motivator untuk meningkatkan kinerja guru dan semua tenaga kependidikan di sekolah/madrasah.

Keputusan Menteri Pendidikan dan Kebudayaan Nomor 0304/U/2001 tentang Struktur Organisasi Departemen Pendidikan dan Kebudayaan, menempatkan pengawas dan penilik sekolah sebagai tenaga dua fungsi. Maksudnya, mereka memiliki posisi jabatan struktural dan juga berposisi pada jabatan 
fungsional. Akan tetapi, dengan keluarnya Keputusan Menteri Pendayagunaan Aparatur Negara (Menpan) Nomor 118/2003 tentang Jabatan Fungsional Pengawas Sekolah dan Angka Kreditnya, pengawas sekolah dan penilik sekolah (kemudian bernama pengawas sekolah) murni menjadi pejabat fungsional. Jabatan struktural yang melekat padanya dilepaskan oleh keputusan tersebut. Sejak itulah pengawas sekolah bertugas sebagai penilai dan pembina bidang teknik edukatif dan teknik adminsitratif di sekolah yang menjadi tanggung jawabnya.

Kendala-kendala yang dialami oleh pengawas adalah sebagai berikut a) tidak adanya pendidikan prajabatan yang jelas bagi calon pengawas; b) sistem rekruitmen tenaga pengawasa sekolah selama ini kurang baik; c) Tidak ada kewenngan yang jelas bagi seorang pengawas sekolah; d) selama ini tidak ada penjenjangan karir yang jelas untuk menduduki jabatan pengawas sekolah; e) selama ini jabatan pengawas nyaris kurang tersentuh pembaharuan.

\section{KEPALA SEKOLAH}

Kepala sekolah adalah guru yang mendapat tugas tambahan sebagai kepala sekolah. Meskipun sebagai guru yang mendapat tugas tambahan, kepala sekolah merupakan orang yang paling betanggung jawab terhadap aplikasi prinsip-prinsip administrasi pendidikan yang inovatif di sekolah. Mulyasa (2002) menyatakan bahwa kepala sekolah dapat didefinisikan sebagai seorang tenaga fungsional guru yang diberi tugas untuk memimpin suatu sekolah dimana diselenggarakan proses belajar mengajar, atau tempat di mana terjadi interaksi antara guru yang memberi pelajaran dan murid yang menerima pelajaran. Anwar (2004) menyatakan bahwa kompetensi yang disyaratkan untuk dimiliki oleh setiap kepala sekolah mengacu pada tiga hal yaitu 1) menunjuk pada karakteristik pribadi pemimpin yang tercermin pada setiap sikap dan tindakannya; 2) mengacu pada suatu kemampuan untuk dapat melaksanakan tugastugasnya sebagai pemimpin yang diperoleh melalui pendidikan dan pelatihan, dan 3) menunjuk kepada suatu kinerja yang bersifat rasional dan memenuhi spesifikasi tertentu dalam melaksanakan tugas. Anwar (2004) menjelaskan bahwa ada beberapa tugas pokok kepala sekolah selaku pemimpin di sekolah, salah satu tugas pokok tersebut adalah selaku manajer, administrator, dan supervisor.

Setiap pemimpin mempunyai pola yang berbeda-beda dalam menerapkan kepemimpinannya. Cara mernpengaruhi, mengarahkan, dan mendorong pemimpin terhadap orang-orang yang dipimpinnya berbeda beda. Perbedaan pola kepemimpinan 
itulah yang sering disebut sebagai tipe kepemimpinan. Menurut Djatmiko (2002) kepemimpinan dapat dikategorikan menjadi lima tipe, yaitu 1) tipe otokratik; 2) tipe paternalistik; 3) tipe kharismatik; 4) tipe laissez faire; dan 5) tipe demokratik.

\section{KINERJA GURU PENDIDIKAN AGAMA ISLAM}

Salim (2000) menyatakan bahwa Istilah kinerja dalam The Contemporary English Indonesian Dictionary diartikan sebagai seseorang yang menjalankan suatu tugas atau proses dengan terampil sesuai dengan prosedur atau ketentuan yang ada. Sementera Fatah (2000) menyatakan bahwa kinerja juga bisa diartikan sebagai ungkapan kemampuan yang didasari oleh pengetahuan, sikap, dan keterampilan serta motivasi dalam menghasilkan sesuatu.

Sebagai suatu konsep dari aktivitas kegiatan kerja, terdapat hubungan antara kinerja, hasil kerja dan satuan waktu yang dibutuhkan untuk menghasilkan produk atau jasa tertentu dari seorang tenaga kerja (labor). Sehingga agar tercipta iklim kerja yang kondusif di mana pekerja dapat lebih giat dan produktif dengan dedikasi sebagai wujud dari pengorbanan tenaga, pikiran, dan waktu demi keberhasilan organisasi.

Kinerja seorang guru dapat dilihat dari sejauh mana guru tersebut mampu melaksanakan tugas dan tanggung jawabnya dengan baik, menggerakkan, memotivasi siswa untuk belajar, dan bekerja sama dengan guru lain. Tugas utama guru sebagaimana disebutkan dalam Undangundang RI Nomor 14 tahun 2005 tentang Guru dan Dosen pada Bab I pasal 1, guru adalah pendidik profesional dengan tugas utama mendidik, peserta didik pada pendidikan anak usia dini jalur pendidikan formal, pendidikan dasar, dan pendidikan menengah.

Kinerja GPAI menyangkut semua aktivitas atau tingkah laku yang dikerjakan oleh seorang guru agama Islam dalam mencapai suatu tujuan atau hasil pembelajaran Pendidikan Agama Islam (PAI). Profesi GPAI bukan hanya sekedar suatu penghasilan, tetapi menyangkut pengabdian pada suatu tugas yang mulia. Sebagaimana firman Allah SWT dalam QS. An-Najm (53) ayat 39-41 berikut "Dan bahwasanya seorang manusia tiada memperoleh selain apa yang telah diusahakannya. Dan bahwasanya usahanya itu kelak akan diperlihatkan (kepadanya). Kemudian akan diberi balasan kepadanya dengan balasan yang paling sempurna”.

Berkaitan dengan kinerja GPAI, hal ini pada dasarnya lebih mengacu pada sikap, atau perilaku pendidik itu sendiri dalam mengejawantahkan kinerjanya kepada 
peserta didik terhadap perilaku yang islami, sehingga para siswa dapat menjadikan gurunya sebagai seorang figur atau sosok yang pantas untuk dijadikan contoh di sekolah dalam bersikap atau berprilaku, dan pada akhimya siswa dapat mengaplikasikan sikap keislamannya dalam kehidupan seharihari.

Perencanaan pengajaran atau desain instruksional membantu guru mengarahkan langkah dan aktivitas kinerja yang akan ditampilkan dalam proses belajar mengajar sebagai usaha mencapai tujuan pembelajaran. Sekurang-kurangnya dalam disain instruksional yang diwujudkan dalam bentuk satuan pembelajaran itu tercakup unsur-unsur tujuan mengajar yang diharapkan, materi/bahan pelajaran yang diberikan, strategi atau metode mengajar yang akan diterapkan dan prosedur evaluasi yang dilakukan dalam menilai hasil belajar siswa.

Dharma (2000) berpendapat bahwa penilaian kinerja pada dasarnya merupakan proses pengambilan keputusan tentang hasil yang dicapai karyawan dalam periode waktu tertentu. Sedangkan menurut Hasibuan (2001) menyatakan bahwa penilaian kinerja berkenaan dengan seberapa baik seseorang melakukan pekerjaan yang ditugaskan atau diberikan, sedangkan evaluasi pekerjaan menentukan seberapa tinggi harga sebuah pekerjaan bagi organisasi, dan dengan demikian, pada kisaran berapa gaji sepatutnya diberikan kepada pekerjaan tersebut.

Penilaian kinerja sangat penting dalam sebuah lembaga pendidikan dan merupakan unsur utama pendidikan, yakni guru dan sekolah. Bagi para guru, hasil penilaian kinerja dapat menimbulkan perasaan puas dalam diri mereka. Dengan cara ini, mereka dapat mengetahui nilai hasil kerja yang dilaksanakan di sekolah, dengan demikian, kelemahan-kelemahan dan kekurangan-kekurangan yang mereka ketahui dari informasi hasil penilaian akan menimbulkan dorongan untuk memperbaiki diri. Sedangkan bagi sekolah, hasil penilaian kinerja dapat dipakai sebagai bahan pertimbangan untuk pengembangan keputusan tentang berbagai hal, seperti kebutuhan program pendidikan dan latihan, seleksi, rekruitmen, penempatan, dan sebagainya.

Meningkatkan kualitas kinerja pegawai atau tenaga kerja (labor) ada tiga aspek yang memiliki pengaruh yang signifikan, yaitu kemampuan, semangat, dan dedikasi. Kemampuan (ability) dari pegawai akan dapat meningkat seiring dengan iklim kerja yang kondusif sehingga muncul inisiatif dan kreatifitas kerja. Sedangkan semangat kerja berkaitan dengan dorongan jiwa seseorang secara psikologis, dan dedikasi merupakan 
sebuah kekuatan yang dimiliki seseorang untuk dapat serius dalam melakukan pekerjaan di bidangnya.

\section{METODE PENELITIAN}

Jenis penelitian ini bersifat kualitatif induktif dengan metode deskriptif. Menurut Cresswell (2008) "an inductive approach aimed at reducing the data into a manageable number of themes that addressed the concerns of the study". Alasan peneliti mengambil penelitian kualitatif dengan metode deskriptif ini adalah sifat dari masalah yang diteliti dalam bentuk mengungkap fakta dan gejala apa adanya saat penelitian dilakukan, kemudian juga dalam bentuk menentukan dan menafsirkan data yang berkenaan dengan situasi yang terjadi di lokasi penelitian tentang usaha pengawas dan kepala sekolah dalam meningkatkan kinerja guru PAI di Kota Solok. Dalam mengumpulkan data yang dibutuhkan, penulis menggunakan teknik pengumpulan data sebagai berikut.

\section{Wawancara}

Teknik wawancara yang digunakan dalam penelitian ini adalah teknik wawancara tidak terstruktur (in-depth interviewing) karena peneliti merasa "tidak tahu apa yang belum diketahuinya". Dengan demikian wawancara dilakukan dengan pertanyaan yang bersifat "open-ended", dan mengarah kepada kedalaman informasi (Sutopo, 2002: 59) dari data primer. Adapun yang diwawancarai dalam penelitian ini adalah sesuai dengan sumber data yang diajukan seperti pengawas, kepala sekolah, guru PAI Kota Solok dan para pejabat lainnya yang terlibat. Kegiatan wawancara ini dilakukan untuk mengetahui kegiatan dan kejadian yang sesungguhnya tentang usaha pengawas dan kepala sekolah dalam meningkatkan kinerja guru PAI di Kota Solok. Sumber data primer adalah pengawas PAI satu orang, dan kepala sekolah 5 orang. Sumber data sekunder adalah guru PAI 5 orang.

\section{Dokumentasi}

Menurut Bungin (2008) dokumen adalah rekaman peristiwa yang lebih dekat dengan percakapan, menyangkut persoalan pribadi dan memerlukan interpretasi yang berhubungan sangat dekat dengan konteks rekaman peristiwa tersebut. Analisis data dilakukan melalui 3 tahap, yaitu data reduction (reduksi data); data display (penyajian data); dan Conclusion Drawing/ Verification (Kesimpulan).

\section{HASIL PENELITIAN}

1. Usaha pengawas dan Kepala Sekolah dalam meningkatkan kinerja guru PAI adalah dengan menjalankan tujuh 
program di antaranya 1) program pembinaan tanggung jawab guru; 2) program pelaksanaan kegiatan pembelajaran; 3) program evaluasi proses pembelajaran; 4) program pembinaan kedisiplinan guru; 5) program pembinaan komitmen guru; 6) program pembinaan loyalitas guru; dan 7) program pemberian motivasi guru.

2. Cara Pengawas dan Kepala Sekolah dalam meningkatkan kinerja guru PAI adalah dengan menempuh jalur penilaian prestasi kerja berupa pemberian nilai DP3 secara adil, memberikan kesempatan kepada semua guru untuk mengikuti penataran di setiap ada kesempatan karena sangat besar manfaatnya terhadap peningkatan kualitas mengajar guru, dan memberikan contoh secara langsung yaitu dari perilaku pengawas dan kepala sekolah sendiri dengan cara datang ke sekolah lebih awal dan pulang lebih akhir. Kendala pengawas dan kepala sekolah dalam peningkatan kinerja guru Madrasah Kota Solok di antaranya meteri banyak sedangkan waktu sedikit, guru belum memahami pentingnya mempersiapkan perangkat pembelajaran, keterbatasan waktu dan penerapan metode, guru belum dapat mengembangkan silabus, serta guru belum rutin mengikuti kegiatan MGMP dan melalaikan kegiatan-kegiatan pokok dan rutin dalam pelaksanaan tugas. Solusi yang dilakukan pengawas dan kepala sekolah dalam mengatasi kendala peningkatan kinerja guru Madrasah Kota Solok di antaranya memperpanjang waktu dan bimbingan, merubah langkahlangkah kegiatan, melakukan bimbingan secara terus menerus, memotivasi guru, memperpanjang waktu kegiatan, serta memberikan motivasi kepada guru yang mengikuti kegiatan, dan memberikan arahan dan bimbingan secara terus menerus kepada guru, agar terlaksana secara maksimal.

3. Alasan Pengawas dan Kepala Sekolah dalam meningkatkan kinerja guru PAI adalah karena adanya program pembinaan tanggung jawab guru yang memungkinkan kegiatan yang akan dilaksanakan berjalan dengan baik, dan mencapai hasil yang baik. Penyusunan program pembinaan tanggung jawab guru ini merupakan bagian dari proses pengelolaan yang memiliki arti penting yang terkait dengan persiapan program pembelajaran, pelaksanaan proses pembelajaran dan evaluasi hasil pembelajaran guru. 


\section{KESIMPULAN}

Kesimpulan hasil penelitian ini yang dihimpun dari beberapa sumber data penelitian terdapat tujuh program kegiatan yang dilakukan oleh pengawas dan kepala sekolah dalam peningkatan kinerja guru Madrasah Kota Solok. Ketujuh program tersebut di antaranya:

1) program pembinaan tanggung jawab guru,

2) program pelaksanaan kegiatan pembelajaran,

3) program evaluasi proses pembelajaran,

4) program pembinaan kedisiplinan guru,

5) program pembinaan komitmen guru,

6) program pembinaan loyalitas guru.

7) program pemberian motivasi guru.

Cara Pengawas dan Kepala Sekolah dalam meningkatkan kinerja guru PAI adalah dengan menempuh jalur penilaian prestasi kerja berupa pemberian nilai DP3 secara adil. Alasan Pengawas dan Kepala Sekolah dalam meningkatkan kinerja guru PAI adalah karena adanya program pembinaan tanggung jawab guru.

\section{Saran}

1. Bagi guru, diharapkan dapat meningkatkan kinerjanya secara optimal seteleh dilakukannya kegiatan supervisi oleh pengawas dan kepala madrasah di Kota Solok;

2. Bagi kepala sekolah, diharapkan dapat dipertahankan kegiatan supervisi ini dengan melakukan secara terus menerus agar dapat menciptakan proses pembelajaran yang optimal; dan

3. Bagi pengawas, diharapkan kegiatan ini dilakukan secara berkelanjutan dan sistematis.

\section{KEPUSTAKAAN ACUAN}

Anwar, Idochi. (2004) Administrasi Pendidikan dan Manajemen Pendidikan. Bandung: Alfabeta.

Arikunto, Suharsimi. (2001). Penelitian Pendidikan. Jakarta: Rineka Cipta.

Bungin. (2008). Data Penelitian Kualitatif. Jakarta: PT Raja Grafindo Persada.

Cresswell, J. W. (2008). Educational Research: Planning, Conducting, and Evaluating Quantitative and Qualitative Research. New York, NY: Prentince Hall.

Dharma, Agus. (2000). Mengangkat Citra dan Martabat Guru. Yogyakarta: Adicita Karyanusa.

Djatmiko. (2002). Pemimpin dan Kepemimpinan Pemerintah. Jakarta: PT. Gramedia Pustaka Utama. 
Echols dan Shadily. (2005). Kamus Inggris Indonesia. Jakarta: PT Gramedia Pustaka Utama.

Fatah. (2000). Kualitas Belajar Mengajar. Jakarta: Balai Pustaka.

Hasibuan. (2001). Manajemen Sumber Daya Manusia. Jakarta: Bumi Aksara.

Mahmudi. (2005). Pengaruh Budaya Organisasi Sekolah dan Kompensasi terhadap Kinerja Guru. Semarang: UNES Press.

Sahertian. (2000). Peranan dan Fungsi Pengawas dalam Pendidikan. Jakarta: Rineka Cipta.
Salim, Peter. (2000). Peningkatan Kinerja Guru. Jakarta: Rineka Cipta.

Sutopo, HB. (2002). Metodologi Penelitian Kualitatif. Surakarta: UNS Press

Thaib, H.M. Amin \& Subagio. (2007). Kepengawasan Pendidikan. Jakarta: Depag RI

Yasin, Anwar. (2000). Standar Kemampuan Profesional Guru SD. IKIP Malang. 